\title{
GENE EXPRESSION OF $\mathrm{H}^{+}$-PUMPS IN PLASMA AND VACUOLAR MEMBRANES OF CORN ROOT CELLS UNDER THE EFFECT OF SODIUM IONS AND BIOACTIVE PREPARATIONS
}

\author{
N. O. KOVALENKO, T. A. PALLADINA \\ Kholodny Institute of Botany, National Academy of Sciences of Ukraine, Kyiv; \\ e-mail: tatiana_palladina@ukr.net
}

Four isoforms of $\mathrm{H}^{+}$-ATPase of plasma membrane: MHA1, MHA2, MHA3, MHA4 are expressed in the corn seedling roots with prevalence of genes MHA3 $i$ MHA4. The exposure of seedlings in the presence of $0.1 \mathrm{M} \mathrm{NaCl}$ activated the expression of MHA4 gene isoform, that demonstrates its important role in the processes of adaptation to salinization conditions. In vacuolar membrane, where potential is created by two $H^{+}$-pumps, sodium ions activated gene expression of only $H^{+}$-ATPase of $V$-type, taking no effect on the expression of $H^{+}$-pyrophosphatase. The seeds pretreatment by synthetic preparations Methyure and Ivine did not affect gene expression of $H^{+}$-pumps. Thus we can suppose that the ability of the above preparations to activate functioning of $\mathrm{H}^{+}$-pumps in the presence of sodium ions is realized at the post-tranlation level.

Ke y word s: Zea mays L., plasma membrane, vacuolar membrane, salt stress, gene expression, $H^{+}$-ATPase, $H^{+}$-PPase, Methyure, Ivine.

$\mathrm{R}$ epresentatives of the animal and plant kingdoms of nature are cardinally different as to their response to the ions of sodium which is vital for the former ones but unnecessary for others; in high concentrations it becomes a toxic element that is displayed at a cell level. In animal's cells $\mathrm{Na}^{+}$ is a necessary participant of metabolic processes, while in plant cells it violates their occurrence. That is why the plant cells try to prevent accumulation of $\mathrm{Na}^{+}$in cytoplasm and thus remove it outside and to vacuolar space with the help of secondary active $\mathrm{Na}^{+} / \mathrm{H}^{+}$-antiporters, which function in the plasma and vacuolar membranes, using energy of electrochemical potentials created on them by primarily active $\mathrm{H}^{+}$-pumps [1].

Differences as to $\mathrm{Na}^{+}$role in these organisms begin from the plasma membrane, since its electrochemical potential is created in the animal cell by electrogenic $\mathrm{Na}^{+}$-pump $-\mathrm{Na}^{+} / \mathrm{K}^{+}$-ATPase, and in plant cells - by electrogenic $\mathrm{H}^{+}$-pump $-\mathrm{H}^{+}$-ATPase [2], the both enzymes belonging to E1-E2-type of transport ATPase. It plays the important role in numerous physiological processes: opening and closing of stomata, osmoregulation, absorption of nutrients, root growth, adaptation to abiotic stresses, salinization conditions in particular [1]. As to functions, the regulation of this enzyme function is rather complex, it is manifested at genetic and molecular level, and it underlies numerous physiological processes in plants [3]. The ability of sodium ions to increase the expression of protein gene of plasma membrane $\mathrm{H}^{+}$ATPase was shown in the cells of glycophyte and halophyte plants [2]. At the same time the increase of this enzyme transport activity in the presence of $\mathrm{Na}^{+}$ in a number of plant species has been established [5-7].

Electrochemical potential on the vacuolar membrane is created by two $\mathrm{H}^{+}$-pumps, the $\mathrm{Na}^{+}$presence activating the functioning of only weaker pump, $\mathrm{H}^{+}$ATPase of vacuolar V-type, and taking no effect on gene expression of its subunit $\mathrm{A}$ and content of enzymatic protein [5, 7]. In contrast to this, the other $\mathrm{H}^{+}$-pump - $\mathrm{H}^{+}$-pyrophosphatase $\left(\mathrm{H}^{+}\right.$-PPase) does not respond to the presence of $\mathrm{Na}^{+}$, and is even hindered $[5,7]$. Thus $\mathrm{Na}^{+}$removal from cell cytoplasm is provided energetically by two $\mathrm{H}^{+}$-pumps, their mechanisms being represented by transport $\mathrm{H}^{+}$-ATPases.

Investigation of the negative response of plant organisms to $\mathrm{Na}^{+}$is important for plant growing practice on salinized soils which area is quickly extended through the global warming of climate. This makes us to search for the ways of increasing salt-resistance in plants. There exists the method of radical activation of salt resistance in plants by implanting foreign genes which code proteins of stronger $\mathrm{Na}^{+}$/ $\mathrm{H}^{+}$-antiporters and their regulatory systems [9]. 
Thus, a search of a safe and cheap (though nonradical) method of increasing salt resistance of plants still remains a very urgent problem. This problem may be settled by using biologically active drugs. Testing of salt-protective ability of a number of compounds has attracted our attention to pyrimidine derivatives which were preparations Methyure (6-methyl-2-mercapto-4-hydroxypyrimidine) and Ivine, (N-oxyde-2,6-dimethylpyridine). The former drug is distinguished by a twice less toxicity (Fig. 1). The elucidation of mechanisms of salt-protective action of Methyure and Ivine, which we have performed earlier, has revealed the ability of Methyure to increase considerably transport activity of $\mathrm{H}^{+}$-ATPases and functioning of $\mathrm{Na}^{+} / \mathrm{H}^{+}$-antiporters in the plasma and vacuolar membranes of root cells [5, 10].

Today the data concerning gene expression of $\mathrm{H}^{+}$-pumps of the plasma and vacuolar membranes in corn plants are uncoordinated and ambiguous, thus, this work is aimed at studying and comparison of their expression level on one object and investigation of the effect of bioactive preparations Methyure and Ivine on these processes in the presence of sodium ions, for revealing availability of their genetic regulation under given conditions.

\section{Materials and Methods}

Experiments were made on corn seedlings (hybrid Oster), which were grown on water culture in Hoagland medium. In a week age they were transferred to fresh medium, which contained $0.1 \mathrm{M}$ $\mathrm{NaCl}$, that is the critical concentation for corn plants, and exposed during 1 and 10 days. The preparations Methyure and Ivine were used by seed retting in their $10 \mathrm{M}$ solutions during a week.

Gene expression was estimated on the basis of accumulation of their transcripts by the method of semiquantitative reverse transcription-polymerase chain reaction (RT-PCR ). To isolate total RNA we used a set of reagents GeneJetTM plant RNA purification mini kit (Fermentas, Lithuania). Quantitative analysis of RNA was performed by spectrophotometry method, and qualitative one - by electrophoresis in $1 \%$ agarose gel under denaturating conditions [11]. Reverse transcription of total RNA $(1 \mu \mathrm{g})$, and amplification was carried out on a amplifier "Tercik" with commercial sets of reagents (Fermentas, Lithuania).

Specific primers to separate isoforms: MHA1, MHA2, MHA3, MHA4, were used to determine the expression level of genes of $\mathrm{H}^{+}$-ATPase of plasma membrane. Primers to the gene which codes a catalytic subunit of V-H $\mathrm{H}^{+}$-ATPase were chosen for determining its expression. Primers were also chosen for a gene of $\mathrm{H}^{+}$-PPase. The expression of gene of corn $\alpha$-tubuline (ZmTUA 5) served as endogenic controller of the reaction proceeding (Table).

PCR amplification included the following stages: initial denaturation $-+95^{\circ}, 3 \mathrm{~min}$, then 25 cycles: $+95^{\circ}$, $30 \mathrm{sec}$; primers association from $+55^{\circ}$ to $+60^{\circ}, 30 \mathrm{sec}$; synthesis $+72^{\circ}, 30 \mathrm{sec}$; at the final stage we performed incubation at $+72^{\circ}, 1$ min and stopped reaction, cooling to $+4^{\circ}$, with the use of negative controls - without cDNA and with total RNA. The amplification product was separated in $1.5 \%$ agarose gel with tris-acetate buffer in the presence of ethidium bromide. Gels were visualized in ultraviolet light and photographed, the photographs were analyzed in GelAnalyzer program.

Coding gene sequences were obtained from information base NCBI (http://www.ncbi.nlm.nih. gov/), primers were selected with the help of Primer Quest program.<smiles>Cc1cc([N+](=O)[O-])nc(S)n1</smiles>

Methyure (6-methyl-2-mercapto4-hydroxypyrimidine)

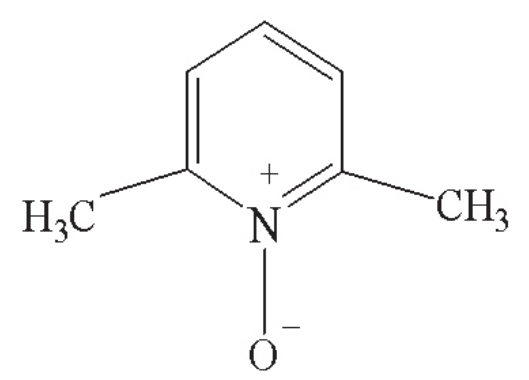

Ivine (N-oxyde-2,6-dimethylpyridine)

Fig. 1. Structure of bioactive drugs Methyure and Ivine 
Ta b l e. Use of primers' sequence in the work

\begin{tabular}{|c|c|c|c|}
\hline Name of the primer & Sequence $\left(5^{\prime}-3^{\prime}\right)$ & $\begin{array}{c}\text { Length of } \\
\text { amplicone (pairs } \\
\text { of nucleotides) }\end{array}$ & $\begin{array}{c}\text { Number of access } \\
\text { to GenBamk }\end{array}$ \\
\hline MHA1 direct & TTTGGAAGTTTGACTTCCCA & \multirow[t]{2}{*}{215} & \multirow[t]{2}{*}{ U09989 } \\
\hline MHA1 inverse & AAGAAGTCGGTCTTGTACGC & & \\
\hline MHA2 direct & AAGACCATGTGTTGCTGTTGGCTG & \multirow[t]{2}{*}{181} & \multirow[t]{2}{*}{ X85805 } \\
\hline MHA2 inverse & TCGGCATCAATGTACGTCAGAGCA & & \\
\hline MHA3 direct & GAGAACAAGACCGCCTTCAC & \multirow[t]{2}{*}{436} & \multirow[t]{2}{*}{ AJ441084 } \\
\hline MHA3 inverse & AAGACGGGTACCCAACCATA & & \\
\hline MHA 4 direct & TCAACGACGGCACTATCATGACCA & \multirow[t]{2}{*}{189} & \multirow[t]{2}{*}{ AJ539534 } \\
\hline MHA 4 inverse & ACCTCACACCGAATTTGTCCGAGA & & \\
\hline V-H+-ATPase direct & ATGGGTTACCCAGCTTACTTGGCT & \multirow[t]{2}{*}{189} & \multirow[t]{2}{*}{ U36436.1 } \\
\hline $\mathrm{V}-\mathrm{H}^{+}$-ATPase inverse & TTGCGGAGGTAACAGGGTCTGAAA & & \\
\hline $\mathrm{H}^{+}$-PPase direct & GACTATTTGGTGCGTTTGTAAG & \multirow[t]{2}{*}{305} & \multirow[t]{2}{*}{ CAG29369.1 } \\
\hline $\mathrm{H}^{+}$-PPase inverse & GATCAGTGGTGTGAGCATAA & & \\
\hline ZmTUA direct & ACGGTTGGGAAGGAGATTGTCGAT & \multirow[t]{2}{*}{106} & \multirow[t]{2}{*}{ NM_001111854.1 } \\
\hline ZmTUA inverse & CACCACCAACAGCATTGAACACCA & & \\
\hline
\end{tabular}

All experiments were performed in three biologic repeats, reliability of results obtained was checked by the Student criterion.

\section{Results and Discussion}

Gene expression profile of four protein isoforms of $\mathrm{H}^{+}$-ATPase of E1-E2-type of plasma membrane - MHA1, MHA2, MHA3 та MHA4 has been shown. The highest expression level was noticed in isoforms belonging to the second subgroup - MHA3 i MHA4, which were in the roots of 8-day seedlings 2.38 and 2.12 conventional units, respectively, while the level of gene expression of the first group was almost 1.5 times lower, being 0.66 in MHA1 and 1.32 in MHA2 (Fig. 2). Under these conditions the relation of their expression levels did not change in 17day seedlings. This demonstrates that the isoforms MHA3 and MHA4 are those which play a leading part in formation of electrochemical potential on the root cell plasma membrane.

Such correlation of isoforms expression at the same plant object was also noted by other authors, thereat the expression of MHA1 isoform was not revealed in some corn hybrids, that points to its incon-
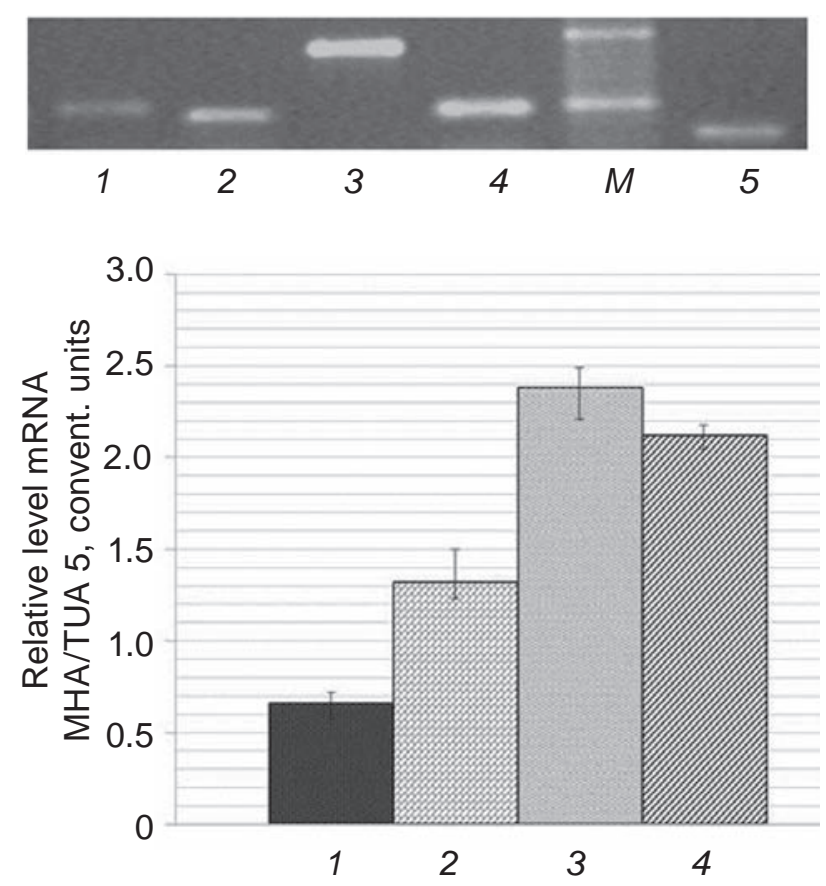

Fig. 2. Gene expression of isoforms of plasma membrane $H^{+}$-ATPase in the corn seedling root cells (8 days): 1 - MHA1, 2 - MHA2, 3 - MHA3, 4 MHA4, 5 - TUA 5- $\alpha$ tubulin 
siderable participation in creating electrochemical potential on the root cell plasma membrane [12].

In our experiments a 1-day exposure of seedlings in $0.1 \mathrm{M} \mathrm{NaCl}$ had no essential effect on correlation of gene expression of the given isoforms of plasma membrane $\mathrm{H}^{+}$-ATPase (Fig. 3), while 10-day expression activated MHA4 isoforms by 30\% with respect to control (Fig. 4). Gene expression activation of MHA4 isoform under salinization was also established earlier in the corn leaf cells [13]. Its expression disturbance under salinization in Arabidopsis plants weakened growth of rosette, correlating with the increase of $\mathrm{Na}^{+} / \mathrm{K}^{+}$relation in the leaves [14]. On this basis it may be considered that the isoform MHA4 of plasma membrane $\mathrm{H}^{+}$-ATPase plays a leading part in plants adaptation to conditions of sodium salinization.

Biologically active preparations used by the authors did not cause any changes in the expression of genes which code isoforms of plasma membrane $\mathrm{H}^{+}$-ATPase (Fig. 5).
Investigation of the expression of genes, coding proteins of two $\mathrm{H}^{+}$-pumps of vacuolar membrane in the roots of 8-day seedlings under control, has revealed a two-fold advantage of $\mathrm{H}^{+}$-PPase gene expression compared with the gene of vacuolar $\mathrm{H}^{+}-$ ATPase (Fig. 6). The difference between them in 17-day seedlings decreased twice at the expense of weakening of $\mathrm{H}^{+}$-PPase gene expression, while no essential changes as to gene expression of vacuolar $\mathrm{H}^{+}$-ATPase were observed (Fig. 7). Correlation was found between accumulation of above enzymes by mRNA and intensification of their transport activity which we observed before [5].

One-day expression of seedlings in the presence of $0.1 \mathrm{M} \mathrm{NaCl}$ had no effect on protein gene expression of the both vacuolar $\mathrm{H}^{+}$-pumps (Fig 6), while its continuation to 10 days activated almost twice just V-H+-ATPase gene (Fig. 7).

It is known that $\mathrm{Na}^{+}$presence in the medium causes a rise of potentials on the plasma and vacuolar membranes [5], and that it occurs on molecular
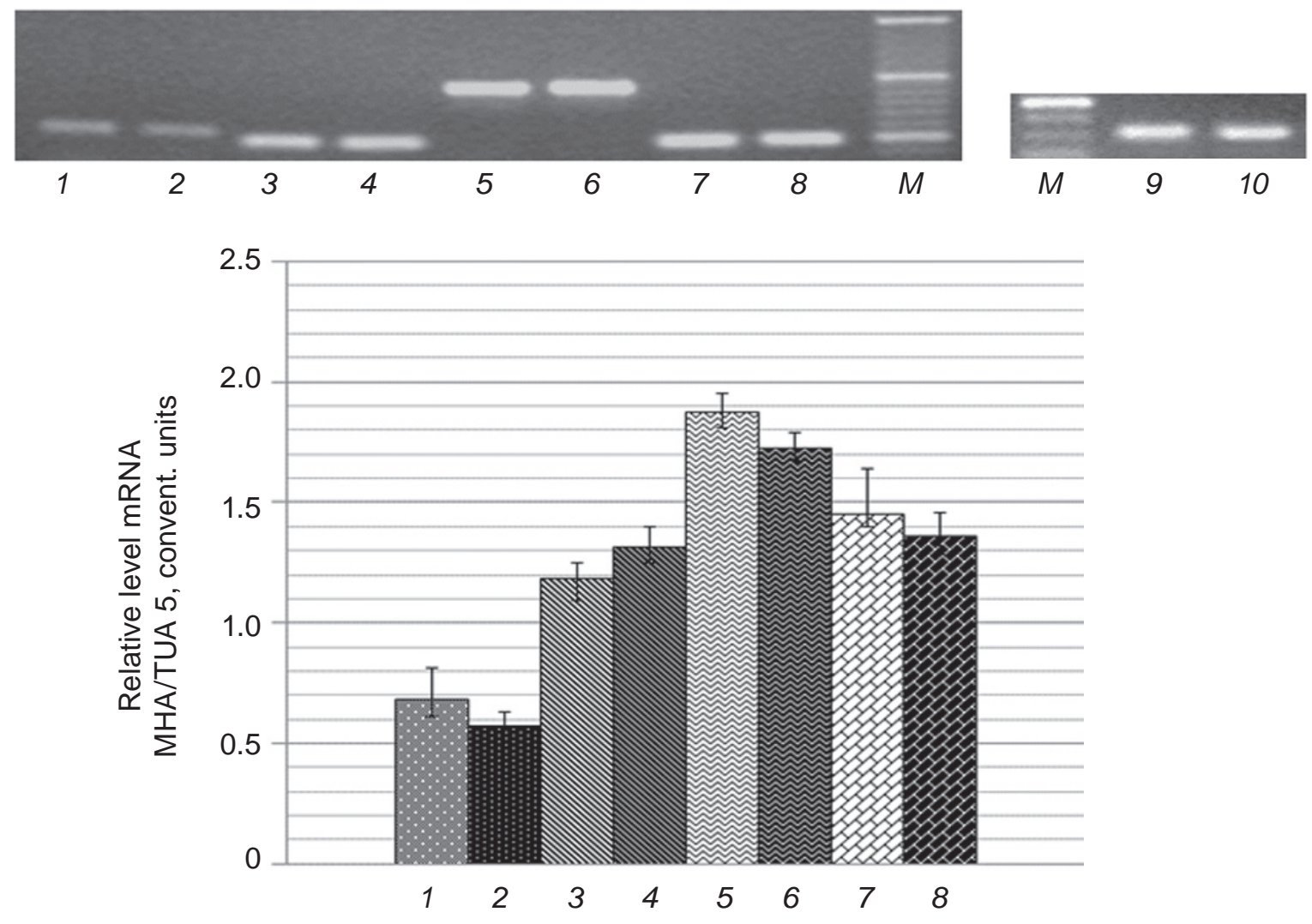

Fig. 3. Gene expression of isoforms of plasma membrane $H^{+}$-ATPase in the corn seedling root cells (8 days) under the exposure in $0.1 \mathrm{M} \mathrm{NaCl}(24 \mathrm{~h}): 1$ - MHA1-control, 2-MHA1-NaCl, 3-MHA2-control, 4-MHA2$\mathrm{NaCl}, 5$ - MHA3-control, 6 - MHA3-NaCl, 7 - MHA4-control, 8 - MHA4-NaCl, 9 - TUA5 control, 10 TUA5- $\mathrm{NaCl}$ 

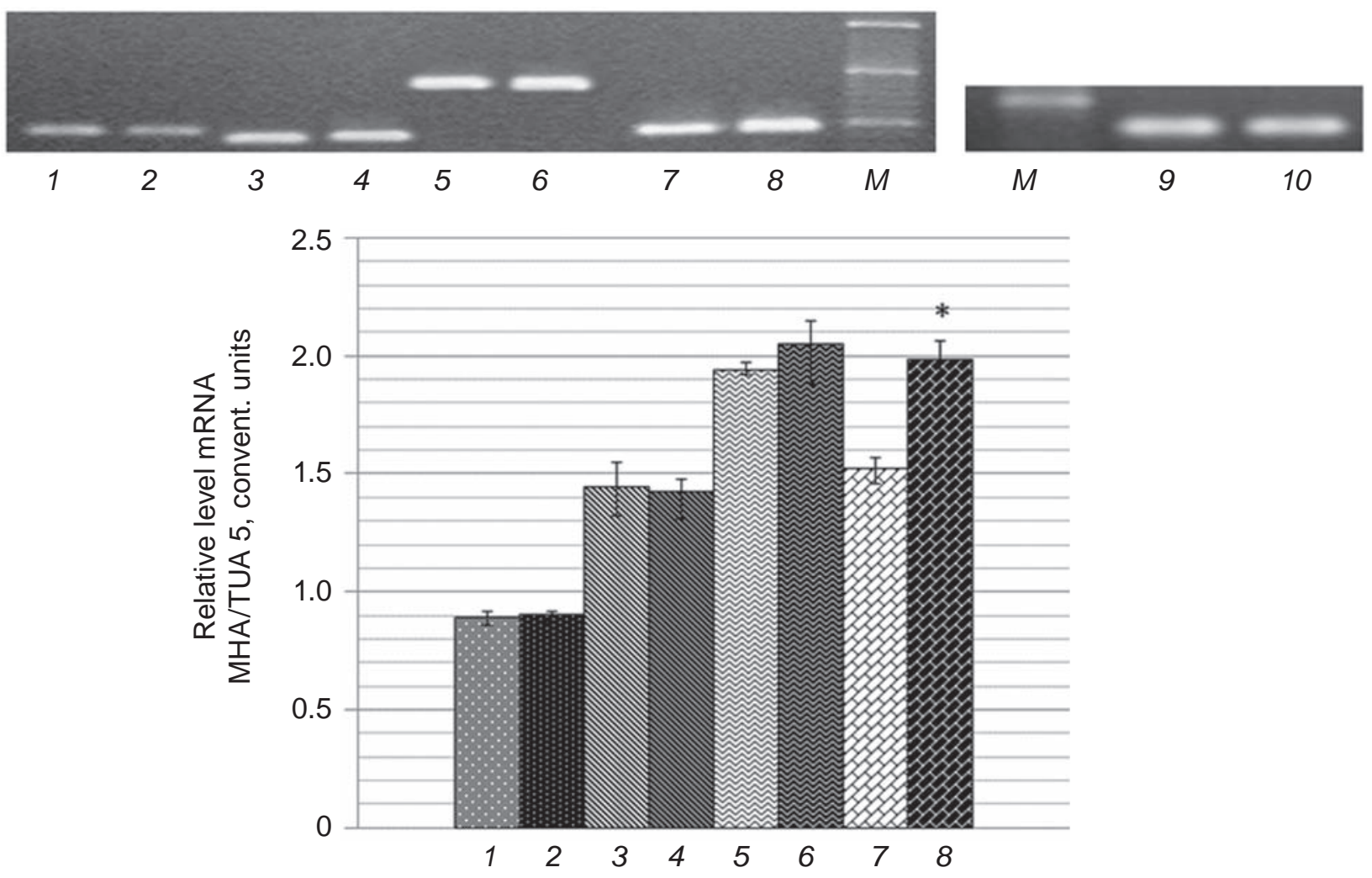

Fig. 4. Gene expression of isoforms of plasma membrane $H^{+}$-ATPase in the corn seedling root cells (17 days) under the exposure in $0.1 \mathrm{M} \mathrm{NaCl}$ (10 days): 1 - MHAl-control, 2 - MHAl-NaCl, 3 - MHA2-control, 4 MHA2-NaCl, 5 - MHA3-control, 6 - MHA3-NaCl, 7 - MHA4-control, 8 - MHA4-NaCl, 9 - TUA5 control, 10 - TUA5- $\mathrm{NaCl}$

and genetic level at the expense of amplification of functioning of $\mathrm{H}^{+}$-pumps, which mechanisms are represented by transport $\mathrm{H}^{+}$-ATPases. At the same time it appeared that biologically active preparations used by the authors, in particular Methyure, which is distinguished by considerable salt-protecting ability, had no effect on the expression of genes coding proteins of $\mathrm{H}^{+}$-pumps in the plasma and vacuolar membranes (Fig. 6, 7). This coincides with the absence of their effect on gene expression of protein of plasma membrane $\mathrm{Na}^{+} / \mathrm{H}^{+}$-antiporter $(10)$.

The results obtained permit supposing that salt-protective effect of the above biologically active compounds, in particular, more efficient preparation Methyure, is realized only at the post-translation level of regulation of $\mathrm{H}^{+}$-pumps. One of the ways of their effect may be mediated by phytohormones, allowing for the data we have obtained before. These data have shown Methyure ability to amplify accumulation of phytohormones ABA and IAA in corn seedling root cells (unpublished data). In turn, it has been shown that adding exogenous ABA stimulated activity of $\mathrm{V}-\mathrm{H}^{+}$-ATPase in the leaves of Mesembryanthemum crystallinum [15] and $\mathrm{H}^{+}$-ATPases of the both membranes in the cucumber seedling roots [8]. Besides, when studying the effect of synthetic growth regulators, including Methyure and Ivine, on the processes of organogenesis in vitro, the authors have also proposed a hypothesis of their phytohormone-mediated action on these processes [16]. The other link of the preparations' effect may also be the regulative effect of phospholipid content of the plasma membrane on the functioning of $\mathrm{H}^{+}$-ATPases, allowing for the ability of these preparations to cause changes in their correlation under salinization conditions [17]. 

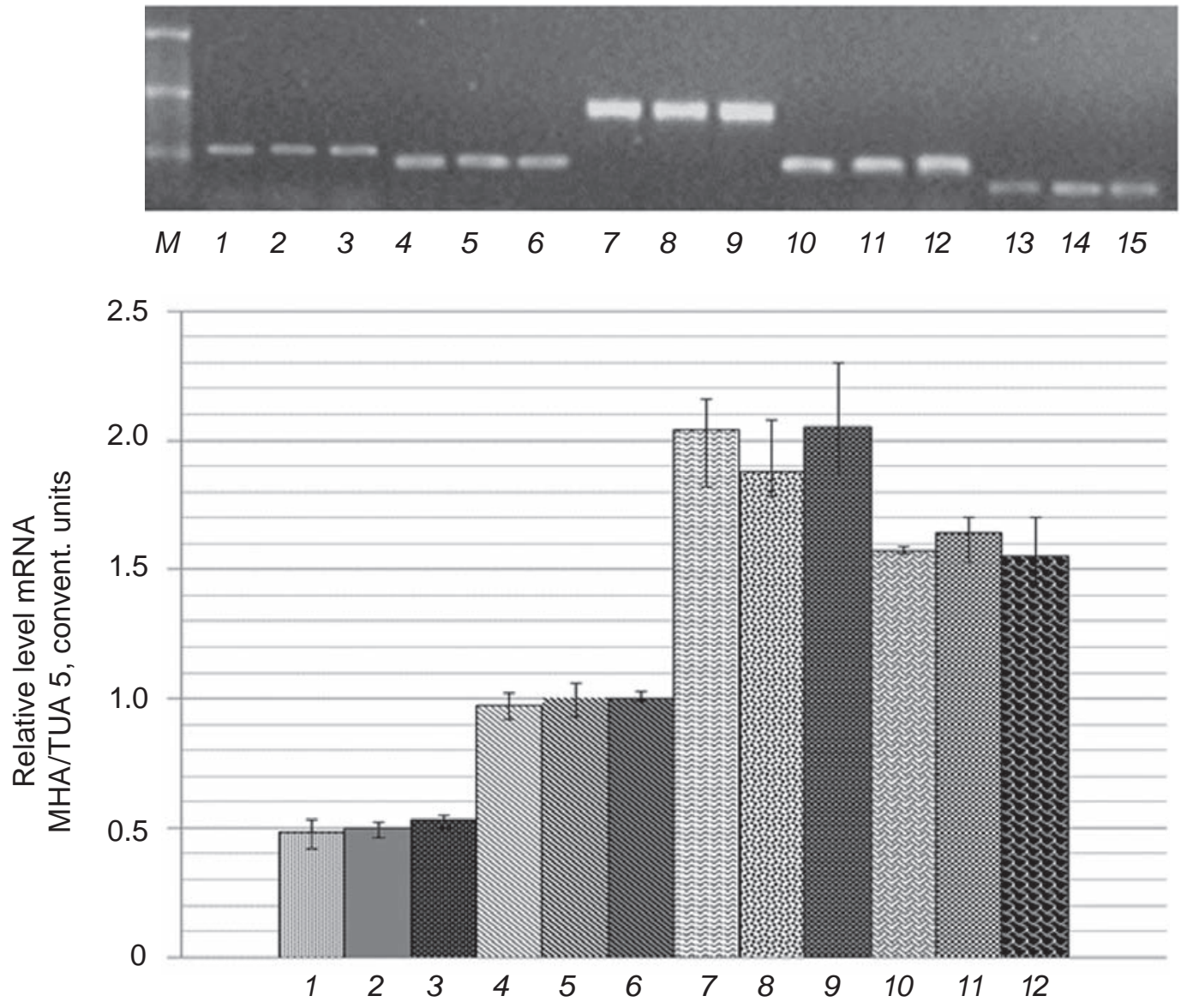

Fig. 5. Gene expression of isoforms of plasma membrane $H^{+}$-ATPase in the corn seedling root cells (8 days) under the effect of drugs Methyure and Ivine: 1-MHA1-контроль, 2-MHA1-Methyure, 3 -MHA1-Ivine, 4-MHA2-control, 5-MHA2-Methyure, 6 MHA2-Ivine, 7-MHA3-control, 8-MHA3-Methyure, 9-MHA3Ivine, 10-MHA4-control, 11 -MHA4-Methyure, 12 - MHA4-Ivine, 13 - TUA 5-control, 14 - TUA 5-Methyure, 15 - TUA 5-Ivine

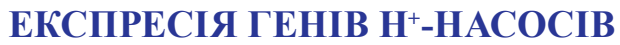 ПЛАЗМАТИЧНОЇ ТА ВАКУОЛЯРНОЇ МЕМБРАН КЛІТИН КОРЕНІВ КУКУРУДЗИ ЗА ДІЇ ІОНІВ НАТРІЮ I БІОАКТИВНИХ ПРЕПАРАТІВ}

\section{Н. О. Коваленко, Т. О. Палладіна}

\author{
Інститут ботаніки ім. М. Г. Холодного \\ НАН України, Київ; \\ e-mail: tatiana_palladina@ukr.net
}

Показано, що в коренях проростків кукурудзи експресуються чотири ізоформи $\mathrm{H}^{+}-$ АТРази плазматичної мембрани: МНA1, МНА2, MHA3, МHA4, серед яких переважає експресія генів МНА3 і МНА4. Експозиція проростків у присутності 0,1 M NaCl посилювала експресію лише гена ізоформи MHA4, що демонструє iï важливу роль у процесах адаптації до умов засолення. У вакуолярній мембрані, потенціал якої створюється двома $\mathrm{H}^{+}$-насосами, іони натрію посилювали експресію гена лише $\mathrm{H}^{+}$АТРази V-типу, не впливаючи на експресію $\mathrm{H}^{+}$-пірофосфатази. Застосування синтетичних препаратів Метіур та Івін шляхом передобробки насіння не позначалось на експресії генів $\mathrm{H}^{+}$-насосів. Таким чином, припускаємо, що показана нами раніше здатність цих препаратів посилювати функціонування $\mathrm{H}^{+}$-насосів $\mathrm{y}$ присутності іонів натрію відбувається на посттрансляційному рівні.

К л ю ч о в і слов а: Zea mays L., плазматична мембрана, тонопласт, сольовий стрес, експресія генів, $\mathrm{H}^{+}$-АТРаза, $\mathrm{H}^{+}$-РРаза, Метіур, Івін. 

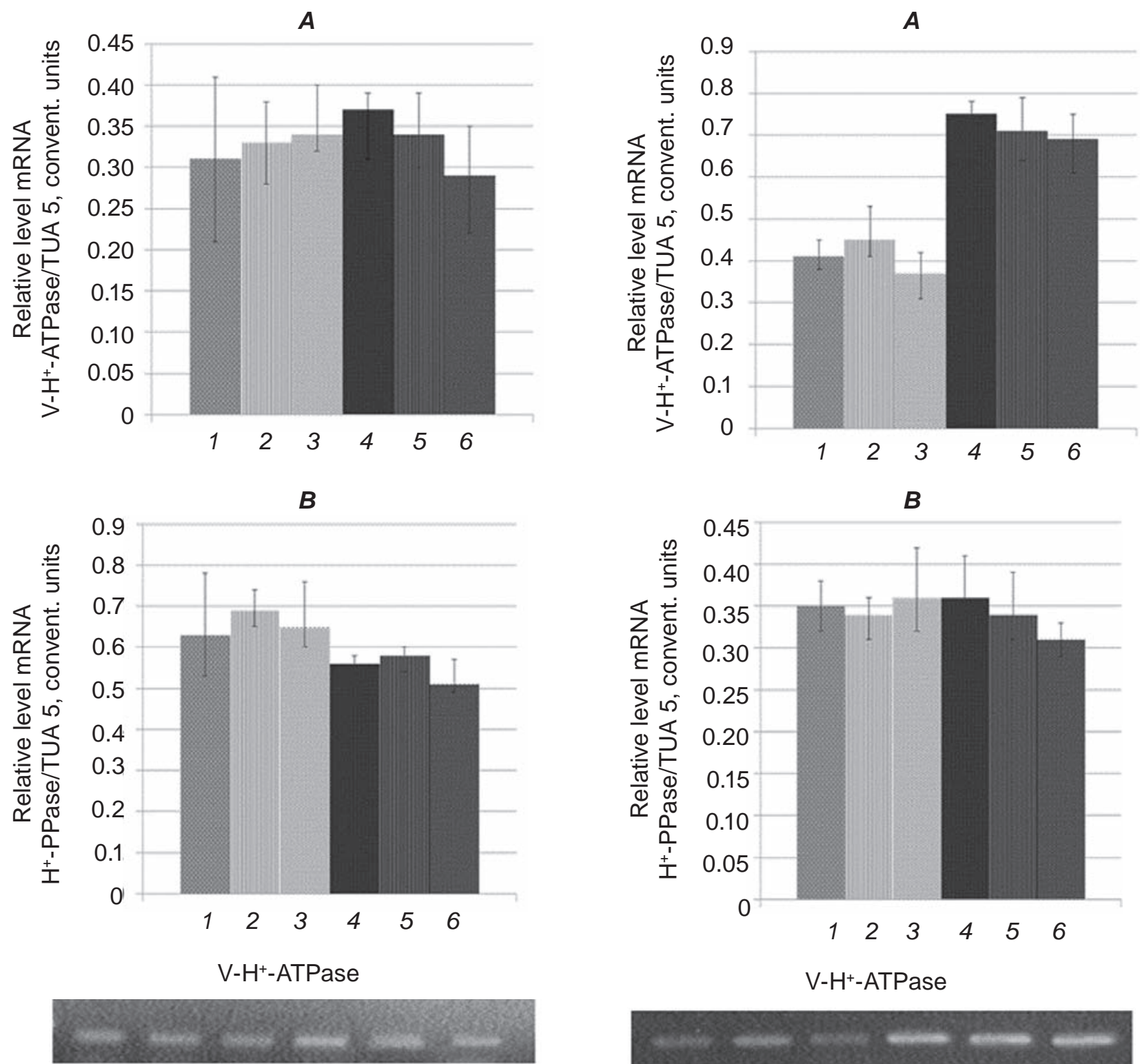

$\mathrm{H}^{+}$-PPase

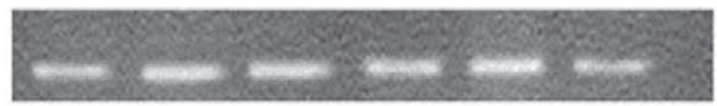

TUA 5

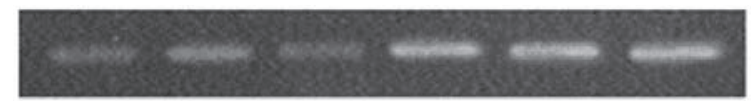

$\mathrm{H}^{+}$-PPase

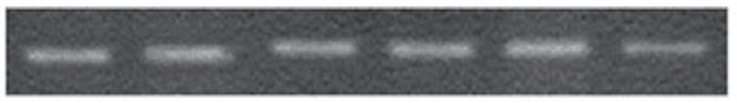

TUA 5

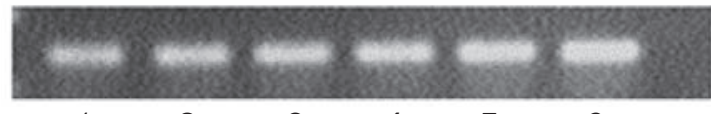

$\begin{array}{llllll}1 & 2 & 3 & 4 & 5 & 6\end{array}$

Fig. 6. Gene expression of $\mathrm{V}-\mathrm{H}^{+}$-ATPase (A) and $\mathrm{H}^{+}-$ PPase (B) of vacuolar membrane in the corn seedling root cells (8 days) under exposure in $0.1 \mathrm{M} \mathrm{NaCl}$ (1 day): 1 - control; 2 - treatment with Methyure; 3 -treatment with Ivine; 4 - control $+0.1 \mathrm{M} \mathrm{NaCl}$; 5 -Methyure + 0.1 M NaCl; 6-Ivine + $0.1 \mathrm{M} \mathrm{NaCl}$; $M-$ marker of molecular weight of DNA, TUA 5- $\alpha$ tubuline 


\section{ЭКСПРЕССИЯ ГЕНОВ Н ${ }^{+}$-НАСОСОВ ПЛАЗМАТИЧЕСКОЙ \\ И ВАКУОЛЯРНОЙ МЕМБРАН \\ КЛЕТОК КОРНЕЙ КУКУРУЗЫ ПРИ \\ ДЕЙСТВИИ ИОНОВ НАТРИЯ И БИОАКТИВНЫХ ПРЕПАРАТОВ}

\section{Н. О. Коваленко, Т. А. Палладина}

\author{
Институт ботаники им. Н. Г. Холодного \\ НАН Украины, Киев; \\ e-mail: tatiana_palladina@ukr.net
}

Установлено, что в корнях проростков кукурузы экспрессируются четыре изоформы $\mathrm{H}^{+}-$ АТР-азы плазматической мембраны: MHA1, MHA2, МНА3, МНА4, среди которых преобладает экспрессия генов МНА3 и МНА4. Экспозиция проростков в присутствии $0,1 \mathrm{M} \mathrm{NaCl}$, усиливала экспрессию только гена изоформы MHA4, которая демонстрирует ее важную роль в процессах адаптации к условиям засоления. В вакуолярной мембране, потенциал которой создается двумя $\mathrm{H}^{+}$-насосами, ионы натрия усиливали экспрессию гена только $\mathrm{H}^{+}$-ATРазы V-типа, не влияя на экспрессию $\mathrm{H}^{+}$-пирофосфатазы. Применение синтетических препаратов Метиур и Ивин путем предобработки семян не влияли на экспрессию генов $\mathrm{H}^{+}$-насосов. Таким образом, предполагаем, что установленная нами ранее способность данных препаратов усиливать функционирование $\mathrm{H}^{+}$-насосов в присутствии ионов натрия происходит на посттрансляционном уровне.

К л ю че в ы е с ло в а: Zea mays L., плазматическая мембрана, вакуолярная мембрана, солевой стресс, экспрессия генов, $\mathrm{H}^{+}$-АТРаза, $\mathrm{H}^{+}$-РРаза, Метиур, Ивин.

\section{References}

1. Janicka-Russak M, Kabala K. The role of plasma membrane $\mathrm{H}^{+}$-ATPase in salinity stress of plants. Progress Botany. 2015; 76: 77-93.

2. Serrano R. Structure and function of plasma membrane ATPase. Annu Rev Plant Physiol Plant Mol Biol. 1989; 40: 61-94.

3. Falhof J, Pedersen JT, Fuglsang AT, Palmgren M. Plasma Membrane $\mathrm{H}(+)$-ATPase Regulation in the Center of Plant Physiology. Mol Plant. 2016; 9(3): 323-337.

4. Niu $X$, Narasimhan ML, Salzman RA, Bressan RA, Hasegawa PM. NaCl regulation of plasma membrane $\mathrm{H}(+)$-ATPase gene expression in a glycophyte and a halophyte. Plant Physiol. 1993; 103(3): 713-718.

5. Rybchenko ZhI, Palladina TO. Function of transport $\mathrm{H}^{+}$-ATPases in plant cell plasma and vacuolar membranes of maize under salt stress conditions and effect of adaptogenic preparations. Ukr Biokhim Zhurn. 2011; 83(6): 63-68. (In Ukrainian).

6. Janicka-Russak M. Plant plasma membrane $\mathrm{H}^{+}$-ATPase in adaptation of plants to abiotic stresses. Abiotic Stress Response in Plants Physiological, Biochemical and Genetic Perspectives. 2011. P.197-218.

7. Kłobus G, Janicka-Russak M. Modulation by cytosolic components of proton pump activities in plasma membrane and tonoplast from Cucumis sativus roots during salt stress. Physiol Plant. 2004; 121(1): 84-92.

8. Janicka-Russak M, Kłobus G. Modification of plasma membrane and vacuolar $\mathrm{H}^{+}$-ATPases in response to $\mathrm{NaCl}$ and ABA. J Plant Physiol. 2007; 164(3): 295-302.

9. Zhu J-K. Salt and drought stress signal transduction in plants. Annu Rev Plant Biol. 2002; 53(1): 247-73.

10. Kovalenko NO, Bilyk ZhI, Palladina TO. Effect of adaptogenic preparations on $\mathrm{Na}^{+} /$ $\mathrm{H}^{+}$-antiporter function in plasma membrane of corn root cells under salinity conditions. $U \mathrm{kr}$ Biochem J. 2014; 86(5): 134-141. (In Ukrainian).

11. Sambrock J, Fritsch EF, Maniatis T. Molecular Cloning. Moscow: Mir, 1984. 479 p. (In Russian).

12. Santi S, Locci G, Monte R, Pinton R, Varanini Z. Induction of nitrate uptake in maize roots: expression of a putative high-affinity nitrate transporter and plasma membrane $\mathrm{H}^{+}$-ATPase isoforms. J Exp Bot. 2003; 54(389): 1851-1864.

13. Zörb Ch, Stracke B, Tramnitz B, Denter D, Sümer A, Mühling KH, Yan F., Schubert S. Does $\mathrm{H}^{+}$pumping by plasmalemma ATPase limit leaf growth of maize (Zea Mays) during the first phase of salt stress? J Plant Nutr Soil Sci. 2005; 168(4): 550-557.

14. Vitart V, Baxter I, Doerner P, Harper JF. Evidence for a role in growth and salt resistance of a plasma membrane $\mathrm{H}^{+}$-ATPase in the root endodermis. Plant J. 2001; 27(3): 191-201.

15. Barkla BJ, Vera-Estrella R, Maldonado-Gama M, Pantoja O. Abscisic acid induction of vacuolar $\mathrm{H}^{+}$-ATPase activity in mesembryanthemum 
crystallinum is developmentally regulated. Plant Physiol. 1999; 120(3): 811-20.

16. Tsygankova VA, Zayets VN, Galkina LA, Blume YaB. The phytohormone-mediated action of the synthetic regulators on cell extension growth in higher plants. Biopolym Cell. 1999; 15(5): 432-441.
17. Konturska OO, Palladina TO. Phospholipid composition of plasmalemma from root of corn seedling under salt conditions and synthetic compounds treatment. Bulletin KNAU. 2007; 2(11): 64-68.

Received 13.10.2015 